\title{
Retention and Escapement Characteristics of Pound Nets as a Function of Pound-Head Mesh Size
}

Henry Louis Meyer

College of William and Mary - Virginia Institute of Marine Science

Follow this and additional works at: https://scholarworks.wm.edu/etd

Part of the Fresh Water Studies Commons, and the Oceanography Commons

\section{Recommended Citation}

Meyer, Henry Louis, "Retention and Escapement Characteristics of Pound Nets as a Function of PoundHead Mesh Size" (1973). Dissertations, Theses, and Masters Projects. Paper 1539617448.

https://dx.doi.org/doi:10.25773/v5-y5v1-t734

This Thesis is brought to you for free and open access by the Theses, Dissertations, \& Master Projects at W\&M ScholarWorks. It has been accepted for inclusion in Dissertations, Theses, and Masters Projects by an authorized administrator of W\&M ScholarWorks. For more information, please contact scholarworks@wm.edu. 


\author{
RETENTION AND ESCAPEMENT CHARACTERISTICS \\ OF POUND NETS AS A FUNCTION OF \\ POUND-HEAD MESH SIZE
}

\begin{abstract}
A Thesis
Presented to

The Faculty of the School of Marine Science

The College of William and Mary in Virginia
\end{abstract}

\author{
In Partial Fulfillment \\ Of the Requirements for the Degree of \\ Master of Arts
}

by

Henry L. Meyer

1973 
ProQuest Number: 10625292

All rights reserved

INFORMATION TO ALL USERS

The quality of this reproduction is dependent upon the quality of the copy submitted.

In the unlikely event that the author did not send a complete manuscript and there are missing pages, these will be noted. Also, if material had to be removed, a note will indicate the deletion.

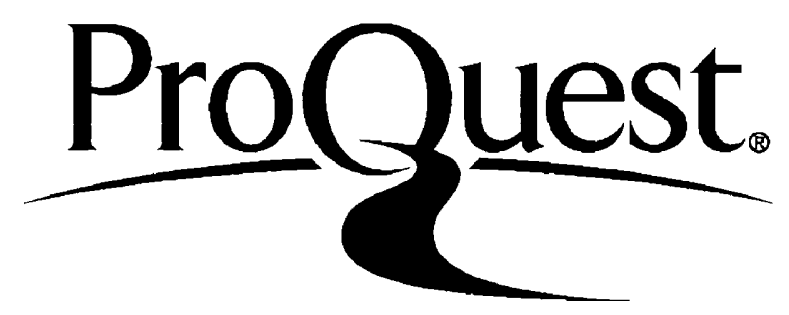

ProQuest 10625292

Published by ProQuest LLC (2017). Copyright of the Dissertation is held by the Author.

All rights reserved.

This work is protected against unauthorized copying under Title 17, United States Code Microform Edition $\odot$ ProQuest LLC.

ProQuest LLC.

789 East Eisenhower Parkway

P.O. Box 1346

Ann Arbor, Ml 48106 - 1346 


\section{APPROVAL SHEET}

This thesis is subritted in partial fulfiliment of the requirments for the degree of Master of Arts

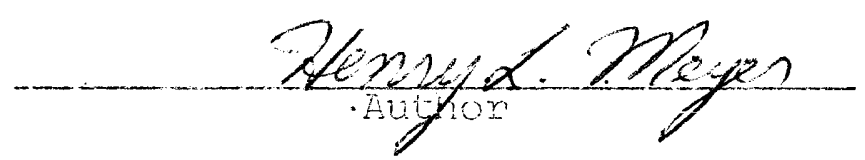

A.percied, Juzy 2073
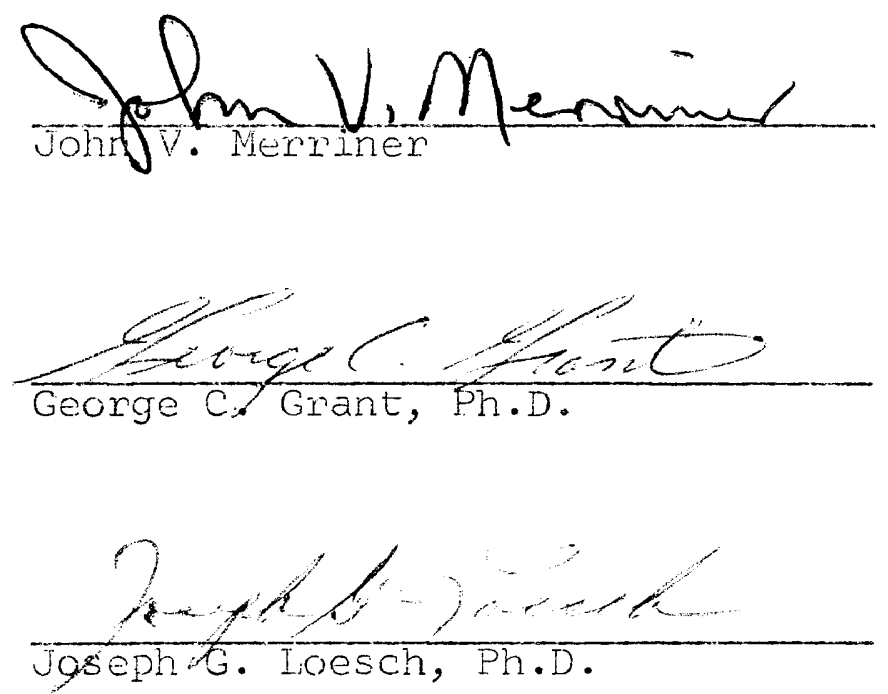
ACKNOWLEDGMENTS • • . • . . • . . . . . . . . . • . . . iV LIST OF TABLES • • • • • • • • • • • • • • • • • • • . V LIST OF FIGURES • • • • • • • • • • • • • • • • • • • • . . vi

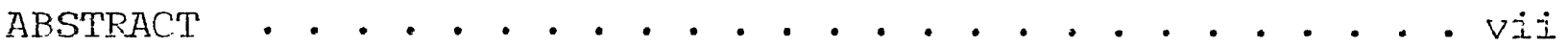
INTRODUCTION MATERIALS AND METHODS • . . . . . . . . . . . . . . . 4 RESULTS • . . . . . . . . . . . . . . . . . . 8

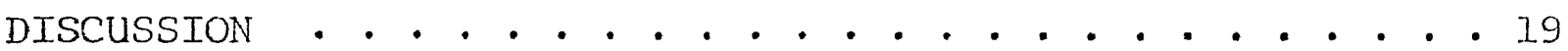
APPENDIX • • • • • • • • • • • • • • • • • • • • • • 27 NOTES • • • • • • . • • • • • • • • • • • • • • . 29

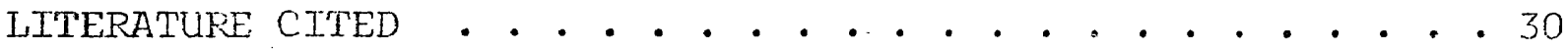
VITA • • • • • • • • • • • • • . • • • . • • . . 32 


\section{ACKNOWLEDGMENTS}

I wish to express my appreciation to Mr. John V. Merriner who so willingly gave of his time in providing new ideas, guidance, and constructive criticism throughout the course of this investigation. I also wish to thank Dr. Joseph G. Loesch, Dr. George C. Grant, Dr. John M. Zeigler, Mr. Melvin Nolan, and Mr. John $J$. Noncross for their effort in review and critical analysis of the ranuscript. Thanks are also due Mr. Mayo Judy and the staff of the National Marine Fisheries Service, Atlantic Estuarine Fishery Center, Beaufort, North Carolina, for use of their research vessel and facilities. Support during this investigation was provided by the Commonwealth of Virginia through the Virginia Institute of Marine Science Department of Ichthyology and by funds made available through The Anadromous Fish Act (P.L. 89--304). 


\section{LIST OF TABLES}

Table

Page

1. New and conditioned stretched mesh sizes in inches and mm with mean stretched mesh measurements and mean mesh circumference and confidence intervals at the 5\% significance level . . . . . . . . . . 7

2. Sample size by species for fishes tested in experimental nets of various stretch mesh ..................... . 11

3. $50 \%$ retention lengths and selection factors derived from experimental data plus theoretical 50\% retention lengths and selection factors computed from regressions for each test species . . . . . 12 


\section{LIST OF FIGURES}

Figure

1. Maximum girth - length relationships for spot (A), menhaden (B), butterfish

(C), weakfish (D), and thread herring

(E) collected in lower Chesapeake Bay. . . . . 15

2. Percentage of fish gilled per length interval

in experimental pound net heads of various

mesh sizes for spot (A), menhaden (B),

butterfish (C), weakfish (D), and thread

herring $(E)$. . . . . . . . . . . . 16

3. Percentage of fish retained (including gilled)

per length interval in experimental pound

net heads of various mesh sizes for spot

(A), menhaden (B), butterfish (C), weakfish

(D), and thread herring (E). . . . . . . . 17

4. Theoretical (solid line) and experimental

(broken line) $50 \%$ retention length data

by species . . . . . . . . . . . . 18 


\section{ABSTRACT}

Lower Chesapeake Bay pound nets have frequently been blamed for the destruction of large quantities of undersized and immature fishes termed "scrap-fish", which include commercially impontant species. Capture of these small fishes is facilitated by the small stretched mesh size of $50.8 \mathrm{~mm}$ (2") commonly used in the entrapment portion of the pound net (=pound-head). Series of five major fishes in scrap landings in the lower Chesapeake Bay were obtained to derive theoretical and experimental 50\% retention lengths, plus gilling frequencies in experimental pound-heads of various stretched mesh sizes. Mesh size tested ranged from $38.1 \mathrm{~mm}$ ( 1 I/2") to $76.2 \mathrm{~mm}$ (3") stretched in $6.4 \mathrm{~mm}\left(1 / 4^{\prime \prime}\right)$ increments.

Significant gilling in stretched mesh sizes of $57.2 \mathrm{~mm}$ (2 1/4") and larger lead to the conclusion that $50.8 \mathrm{~mm}$ (2") stretched mesh in pound-heads is a necessary though wasteful compromise. An escape panel of larger mesh size could be located in the pound-head, which would allow escapement of small sciaenids while retaining clupeids for bait in the blue crab fishery. In situ mesh size measurements are necessary when determining selectivity characteristics of a particular pound-head. 
RETENTION AND ESCAPENEIN CHARACTERIOTICS OF POUND NETS AS A FUNCTION OE PUUND-HEAD MPSH SIZE 


\section{INTRODUCTION}

Pound nets have been an important fishing gear in lower Chesapeake Bay since 1880 (Rejd, 1955). They still contribute a significant percentage of the commercial catch although their use has diminished in recent years 1 .

This fishing device was first introduced in Chesapeake Bay in 1858 (True, 1887) against the wishes of local fishermen. Its potential for capturing large quantities of fish was soon realized. Found nets revolutionized Virginia's fisheries by greatly increased landings and greater diversity of species narketed.

Design and operation of pound nets in lower Chesapeake Bay has changed very little in recent years and was described by Reid (1955). The size of stretched mesh in the entrapment portion of the net (termed the pound-head) is commonly $50.8 \mathrm{~mm}$ (2 in) and it determines selectivity of the pound net.

Use of pound nets has been cited as the cause for declines in the catch of important food species such as the weakfisin (Cymoscion regalis) and destruction of undersized on immature fjshes (Higgins and Pearson, 1928). Undersized or "scrap" fishes include both comercially important species and species not presently maricetabie.

The Genanal Assembly of Virginia passed a law in 1952 which required the Wingina Fisheries Iuboratory and the connission of Fisheries to ascertain "the proper size mesh fox nets in 
fixed fishing devices" while balancing "the interest of consenvation and a suitable catch." (Title 28-25.1 of the code of Virginia). This report provides a portion of the baseline data needed for this determination.

Joseph (1962) listed five species of major importance in. the scrap landings from lower Chesapeake Bay: menhaden, Brevoortia tyrannus; butterfish, Peprilus triacanthus; weakfish, Cynoscion regalis; spot, Leiostomus xanthurus; and thread herring, Opisthonema oglinum. These species represented approximately 90 percent of the scrap fish landed in that area.

My objectives were 1) to determine theoretical selection of pound-heads by mesh size based on morphometric data; 2) to field test predicted results and determine empirical gilling frequencies for the above five species; and: 3) recommend a "proper size mesh" for the pound net fishery in lower Chesapeake Bay • 


\section{MATERIALS AND METHODS}

Morphometric data were obtained from menhaden, butterfish, weakfish, spot, and thread herring captured between 21 June and 6 August, 1971 in pound nets located in the York River, near New Point Comfort, and near Cape Henry, Virginia. Data included fork length in mm (menhaden, butterfish, and throad henring), total length in mn (weakfish and spot), maximum ginth in ron (all species), opercular girth in $\mathrm{mm}$ taken at the posterior margin of the operculum (all species), maximum body depth in rom (all species), and maximum body width in nm (all species). A ginthoneter (Wydoski and Wolfert, 1968) was used for opercular and maximum girth determinations on menhaden, butterfish, spot, and thread herring. The relatively soft abdomen of the weakfish resulted in biased. girth measurements with this device. Opercular and maximum ginth of this species were determined by placing a fine string around the fish body and recording circumference.

All data were analyzed by model. I regression on an IBM 1130 computer. Maxinum girth was selected as the factor best determining fish escapement through a given mesh size.

Hive fishes necessary for the field study of selection were obtained between 15 iune 1972 and 17 April 1973 from found nets in the York ark Rappanannock Rivers and by experimental otten trawls in the York Ever, and of Beanfort, N.C. 
Seven experimental nets were constructed in the form of a pound-head without a funnel. The nets ranged in sizes of stretched mesh, as advertised, from $38.1 \mathrm{~mm}$ ( $1 \mathrm{l} / 2 \mathrm{in}$ ) to $76.2 \mathrm{~mm}$ ( $3 \mathrm{in}$ ) in $6.4 \mathrm{~mm}$ ( $1 / 4 \mathrm{in})$ increments. The nets measured $1.83 \mathrm{sq} \mathrm{m}$ and were $1.52 \mathrm{~m}$ deep. AlI nets were hung on a one-thind basis ${ }^{2}$ and coated with anti-fouling copper paint. A holding net measuring $3.05 \mathrm{sq} \mathrm{m}$ by $1.52 \mathrm{~m}$ deep was constructed similarly from $25.4 \mathrm{~mm}$ ( 1 in) stretch mesh nylon netting. The holding net was secured to stakes in approximately $1.5 \mathrm{~m}$ of water (MHW). Each experimental net was suspended in turn within the holding net during tests.

Live fishes were transported to the site on the lower York. River and placed in an experimental net. The fishes were allowed approximately I hour to become familar with the net and assume "normal" behavior. The experimental net was then fished like an actual pound-head and removed from the holding net. Fishes retained by the experimental net were measured for length and released. The holding net was then fished in similar manner and fishes which had escaped the experimental net were measured and released. Lengths of all fishes "gilled" in the experimental net were also recorded.

The above method was altered during the later phases of the field program in an effort to conserve live specimens. The final method utilized one sample of live fishes in up to five experimental nets. Live fishes of known length were placed in the test net of smallest mesh size in a series and allowed to acclimatize for approximately one houn. This net was thon fished. Fishes retained or "gillod" were neasured for length and placed in the 
net of next larger mesh size staked adjacent to the finst net. Lengths of escaped fishes were determined by deletion from the original data of those retained or "gilled." This procedure was repeated sequentially for each test net in the series. Damaged fishes or those exhibiting irregular behavior were removed from the experimental sample when first observed. Theoretical and experimental 50\% retention lengths were derived where data were available for each mesh size to determine selectivity values for five test species of fish. The maximum permissible gilling frequency for a given fish length was chosen to be $20 \%$.

Stretched mesh size of the seven experimental nets was measured with a dial caliper after completion of the field tests. Ten meshes on each test net were randomly selected and measured with slight tension on the mesh. Mesh circumference was determined by inserting an Imhoff cone into each of the selected meshes. The circumference of the cone at the point of maximum penetration in the mesh was recorded in millimeters. Measurements were taken from wet, well seasoned, copper-treated nets. Stretched mesh measurements from new, untreated, dry material used in construction of the nets and manufacturer's adventised stretched mesh sizes were included for comparative purposes. Hean and confidence interval ( $\alpha=0.05)$ for each measurenent of mesh size was determined (Table I). 


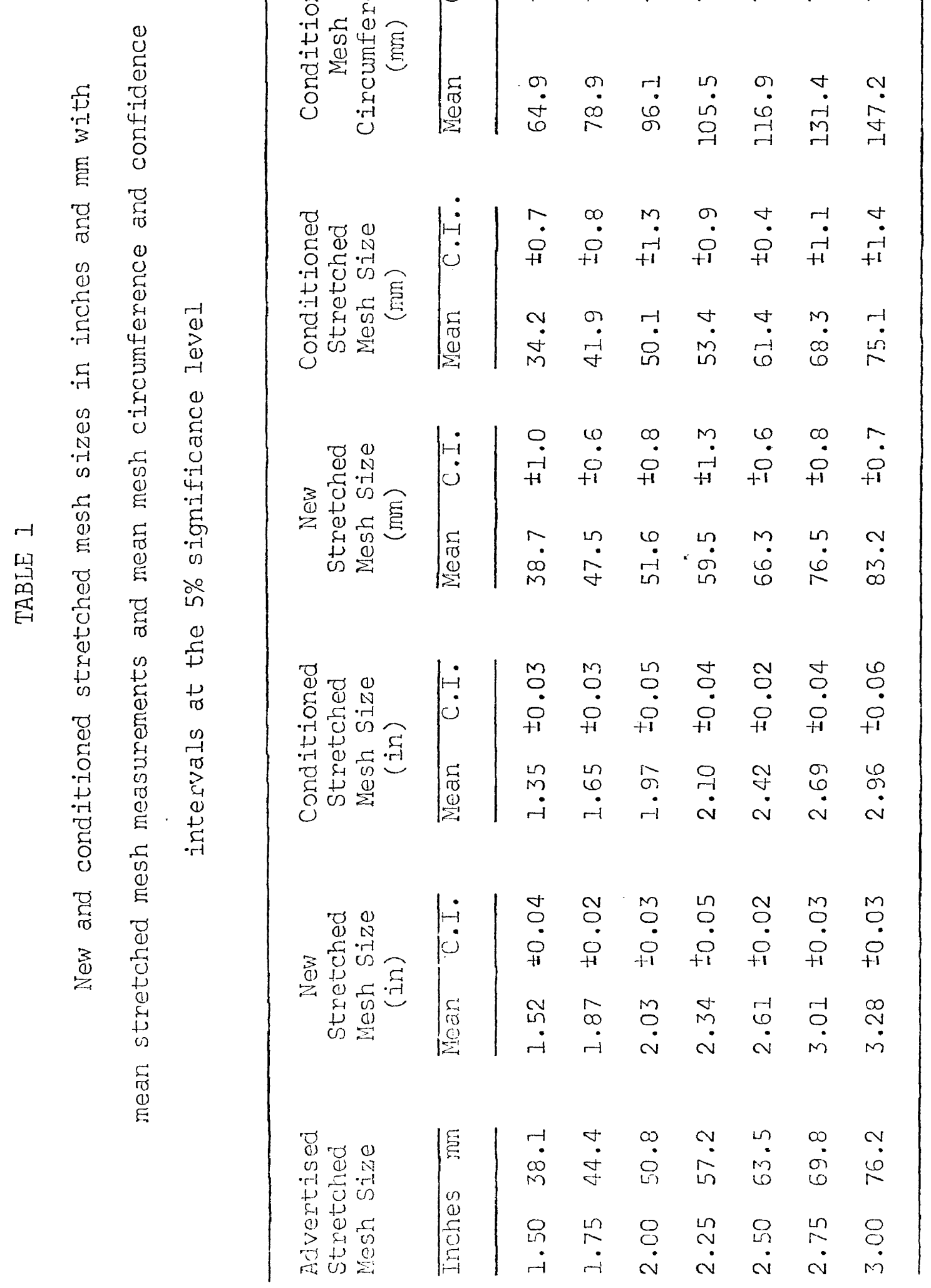


RESUITS

Relationships of maximun ginth to fish length were linear for spot, menhaden, butterfish, and weakfish (Fig. 1). Approximately 210 fish of each species were measured and the relationship expressed as length (mm) $=a+b \operatorname{maximum~girth~(mm).~A~}$ semilogarithmic transformation was applied to convert threat herring data to linearity (Fig. I-E). Reasonably high coefficients of detemination $\left(r^{2}\right)$, ranging from 0.76 to 0.93 , were obtained with the exception of weakfish $\left(r^{2}=0.58\right)$.

Theoretical 50\% retention lengths were derived from the maximum girth-fish length regression for each species, and are defined as the fish length corresponding to a maximum girth value equal to the mean mesh circumference of a given test net. It was assumed the mesh would conform perfectly to the body of an escaping fish. Theoretical values were obtained by entering the ondinate at the appropriate maximum girth/mean mesh size value and reading fish length from the abscissa. The 50\% retention length is that length at which $50 \%$ of the fish of a given species entering a net escape and 50\% are retained. Lengths of retained, gilled, and escaped fishes for a given experimental net were combined by species over $5 \mathrm{~mm}$ increments and data smoothed by a ruming nean of three increments (rigs. 2 and 3 ). An attempt was mate to obtain a minimum total sample size of 100 fish of each species per exporimental not (Table 2). 
A general trend of increased gilling with increased mesh size occurred for all test species (Fig. 2). The 50\% retention length derived from field tests increased with mesh size except for weakfish (Fig. 3). Selection curves were developed from the percentage of a given species in each length interval that were retained in a given mesh size net.

An advertised stretched mesh size of $69.8 \mathrm{~mm}(23 / 4 \mathrm{in})$ or $76.2 \mathrm{~mm}$ ( $3 \mathrm{in}$ ) retained nearly all weakfish over 308 and $313 \mathrm{~mm}$ total length respectively and all spot over $213 \mathrm{~mm}$ total length (Fig. 3). Significant gilling (greater than 20\%) occurred for all five species tested (Fig. 2).

An advertised stretched mesh size of $63.5 \mathrm{~mm}(21 / 2 \mathrm{in})$ retained all weakfish over $293 \mathrm{~mm}$ total length and all spot over $188 \mathrm{~mm}$ total length. Weakfish (242. to $299 \mathrm{~mm}$ total length) exceeded the $20 \%$ level of gilling with a maximum (60\%) at $268 \mathrm{~mm}$. Spot exceeded $20 \%$ gilled in the size range 171 to $192 \mathrm{~mm}$ total length with a maximum (47\%) at $183 \mathrm{~mm}$. Thread herring became gilled in quantities over the permissible level with a maximum (78\%) at $168 \mathrm{~mm}$. Small quantities of menhaden and butterfish were gilled in this size mesh.

Data for the $57.2 \mathrm{~mm}$ (2 $1 / 4 \mathrm{in}$ ) net were examined with similar results. Weakfish over $223 \mathrm{~mm}$ and spot over $173 \mathrm{~mm}$ were retained. Spot (157 to $177 \mathrm{~mm}$ total length) exceeded the $20 \%$ level with maximum gilling (38\%) at $168 \mathrm{~mm}$. Menhaden exceeded $20 \%$ gilled in the size range 136 to $171 \mathrm{~mm}$ fork length with a maximum (50\%) at $153 \mathrm{~mm}$. Thread herring exceeded the permissible level of gilling with a maximum (76\%) at $166 \mathrm{~mm}$. Sufficient gilling data were not available for weakfish and butterfish. 
Theoretical 50\% retention values were greater than experimental values for butterfish and thread herring, but were less than experimental values for spot and weakfish (Fig. 4). Experimental and theoretical lengths agreed closely for menhaden. The 50\% retention length and net mesh size may be expressed as a constant (=selection factor) which is equal to the $50 \%$ retention length divided by stretched mesh size (Table 3). Regression equations, coefficients of determination $\left(r^{2}\right)$, sample size $(n)$, and ranges in fish length for morphometric data. obtained from each species are sumnarized in Appendix A. 
TABLE 2

Sample size by species for fishes

tested in experimental nets of various stretch mesh

\begin{tabular}{cccccc}
\hline $\begin{array}{c}\text { Mesh Size } \\
\begin{array}{c}\text { Stretched } \\
\text { (in) }\end{array}\end{array}$ & Menhaden & $\begin{array}{c}\text { Thread } \\
\text { Herring }\end{array}$ & Spot & Butterfish & Weakfish \\
\cline { 1 - 2 } $11 / 2$ & 211 & 20 & 113 & 22 & 41 \\
$13 / 4$ & 241 & 117 & 140 & 20 & 68 \\
2 & 334 & 121 & 106 & 21 & 118 \\
$21 / 4$ & 276 & 63 & 106 & 100 & 83 \\
$21 / 2$ & 279 & 22 & 135 & 136 & 116 \\
$23 / 4$ & 113 & 80 & 103 & 103 & 88 \\
3 & 104 & 63 & 80 & 139 & 65 \\
\hline
\end{tabular}




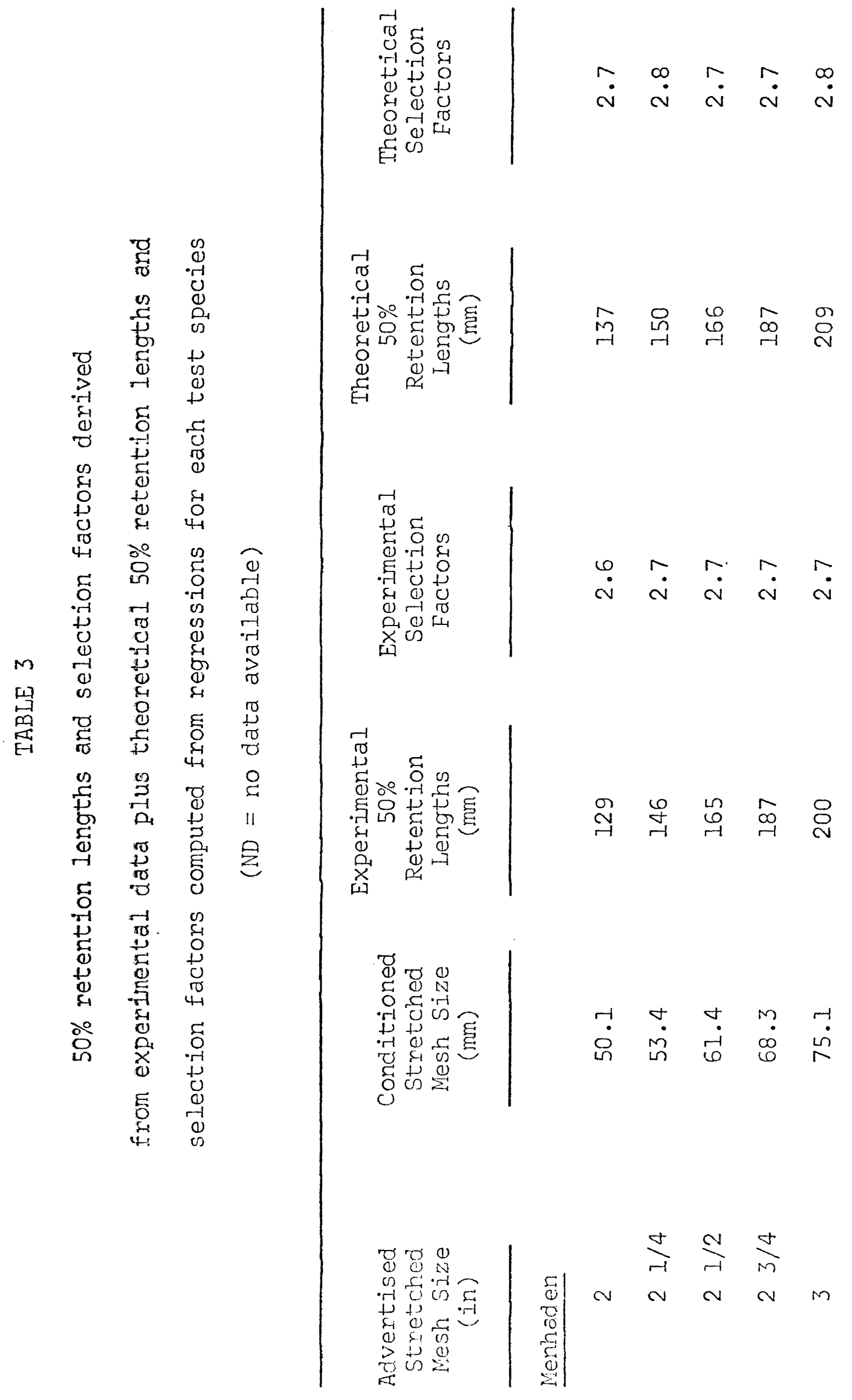




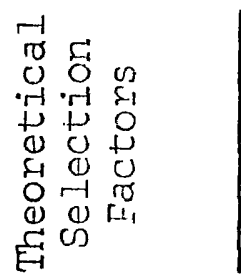

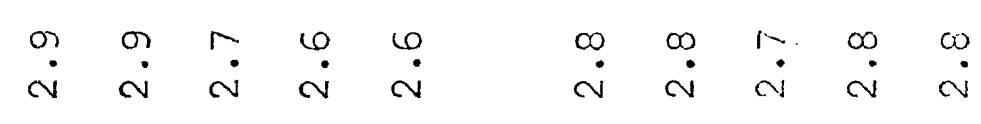

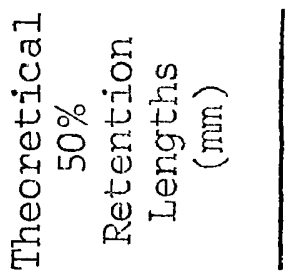

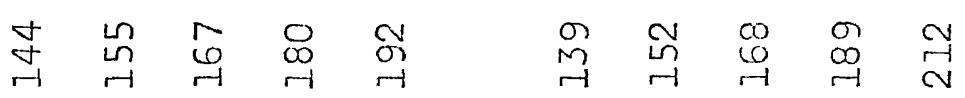

궁

苾

की

जु

r $\begin{array}{r}7 \\ \text { \& }\end{array}$

0 r 10

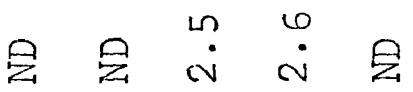

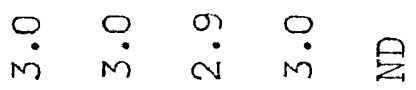

莣

品品

是

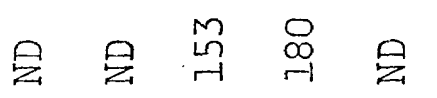

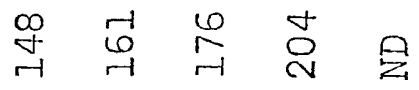

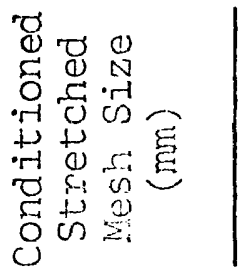

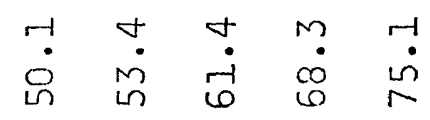

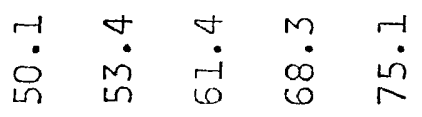

पु)

o.

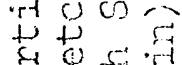

a)

$\geq \pm 0$

प्र

$\stackrel{-1}{\infty} \underset{-1}{\infty}$

$\sum_{-1}^{+-1} \frac{d}{m}$

$N \quad N \quad N \quad M$

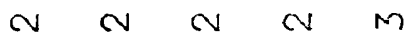




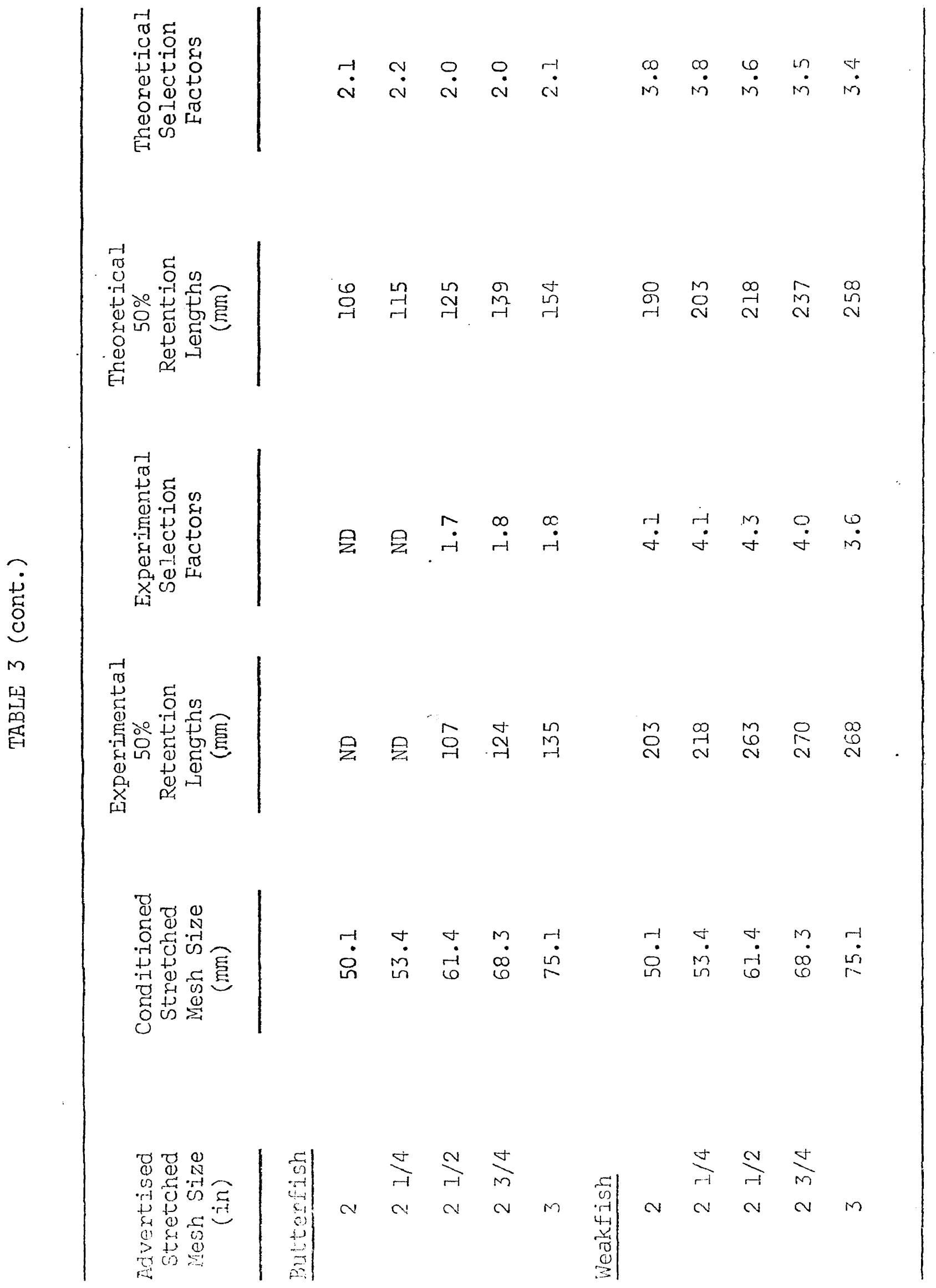


Figure 1. Maximum girth-length relationships for spot $(A)$, menhaden (B), butterfish (C), weakfish (D), and thread herring (E) collected in lower Chesapeake Bay. (Note thread herring relationship is semilogarithmic). 

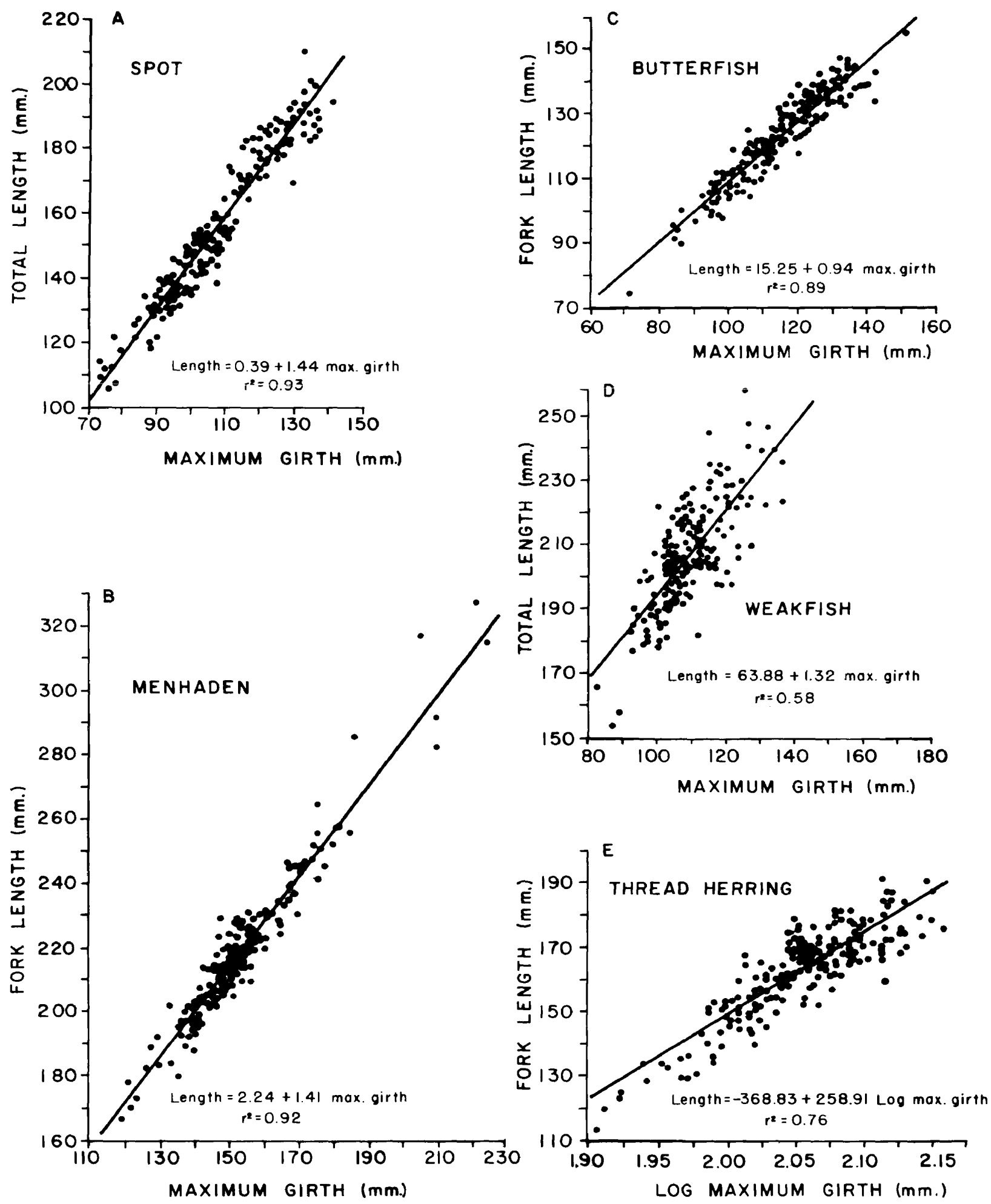
Figure 2. Precentage of fish gilled per length interval in experimental pound net heads of various mesh sizes for spot (A), menhaden (B), butterfish (C), weakfish (D), and thread herring ( $E$ ). (Curves smoothed by running averages of three length increments; lines fitted by eye). 


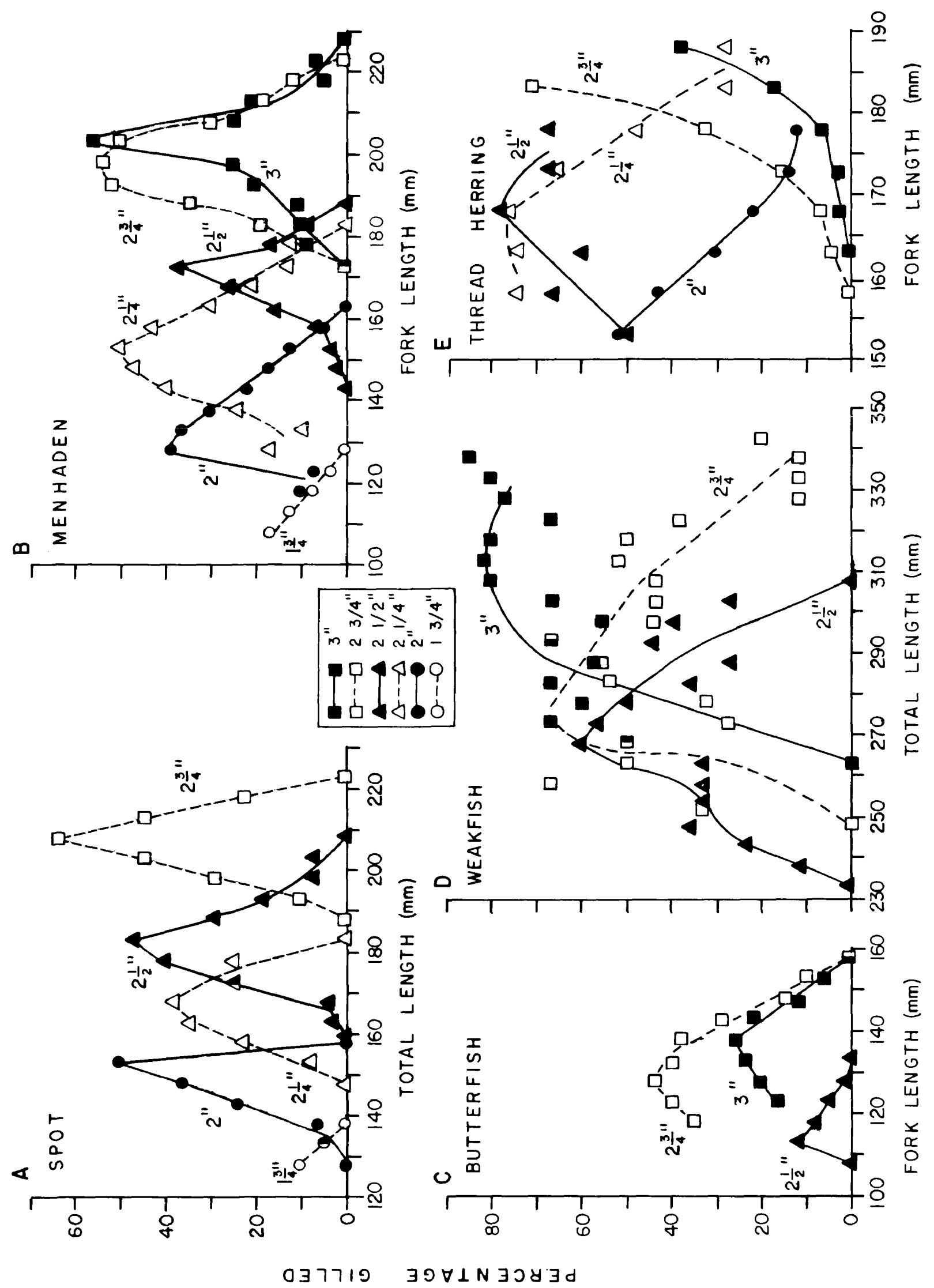


Figure 3. Percentage of fish retained (including gilled) per length interval in experimental pound net heads of various mesh sizes for spct (A), menhaden (B), butterfish (C), weakfish (D), and thread herring (E). (Curves smoothed by running averages of three length increments; lines fitted by eye). 


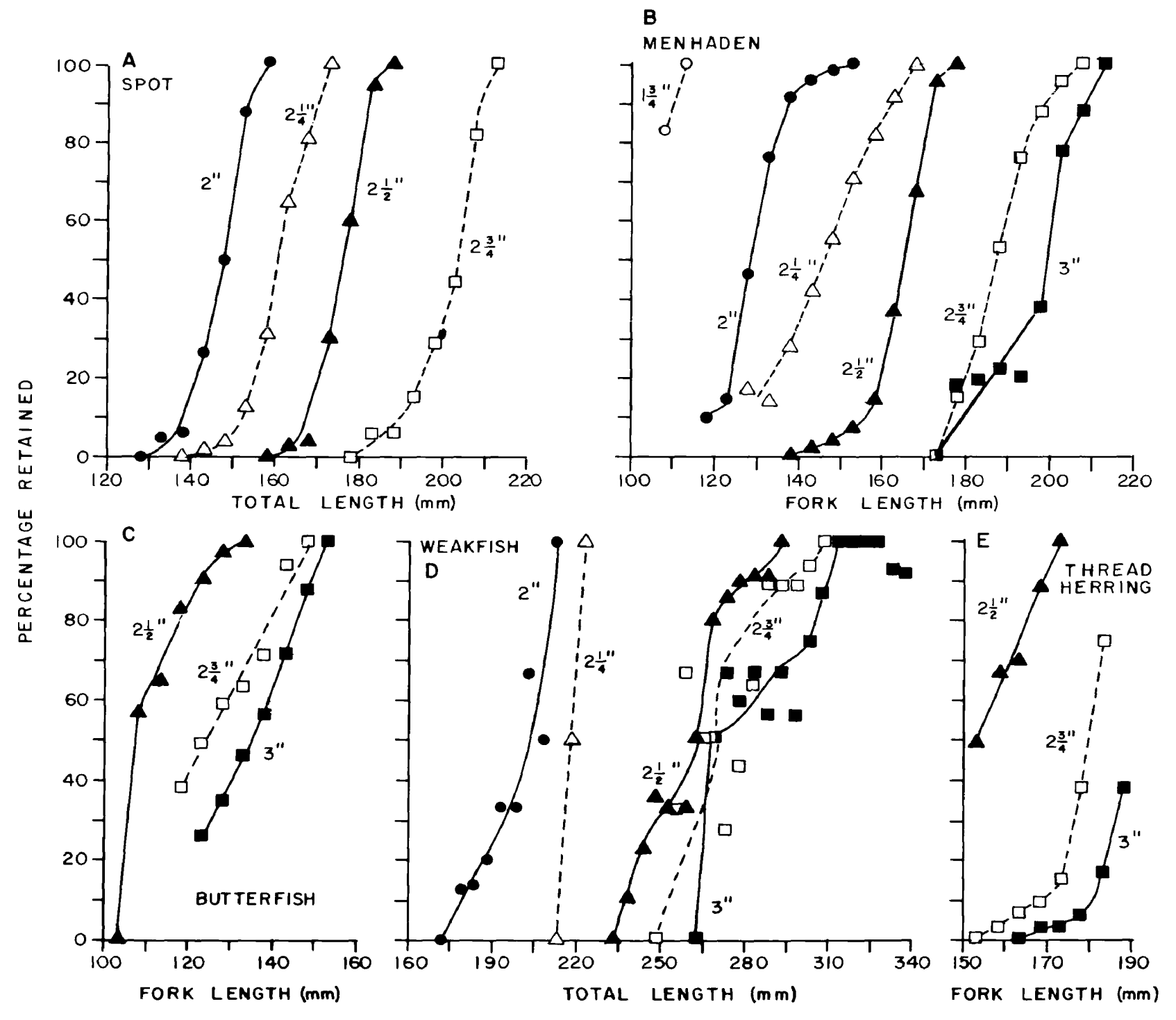


Figure 4. Theoretical (solid line) and experimental (broken line) $50 \%$ retention length data by species. (Conditioned mean mesh circumferences in $\mathrm{mm}$ are plotted; advertised stretched mesh size is noted). 


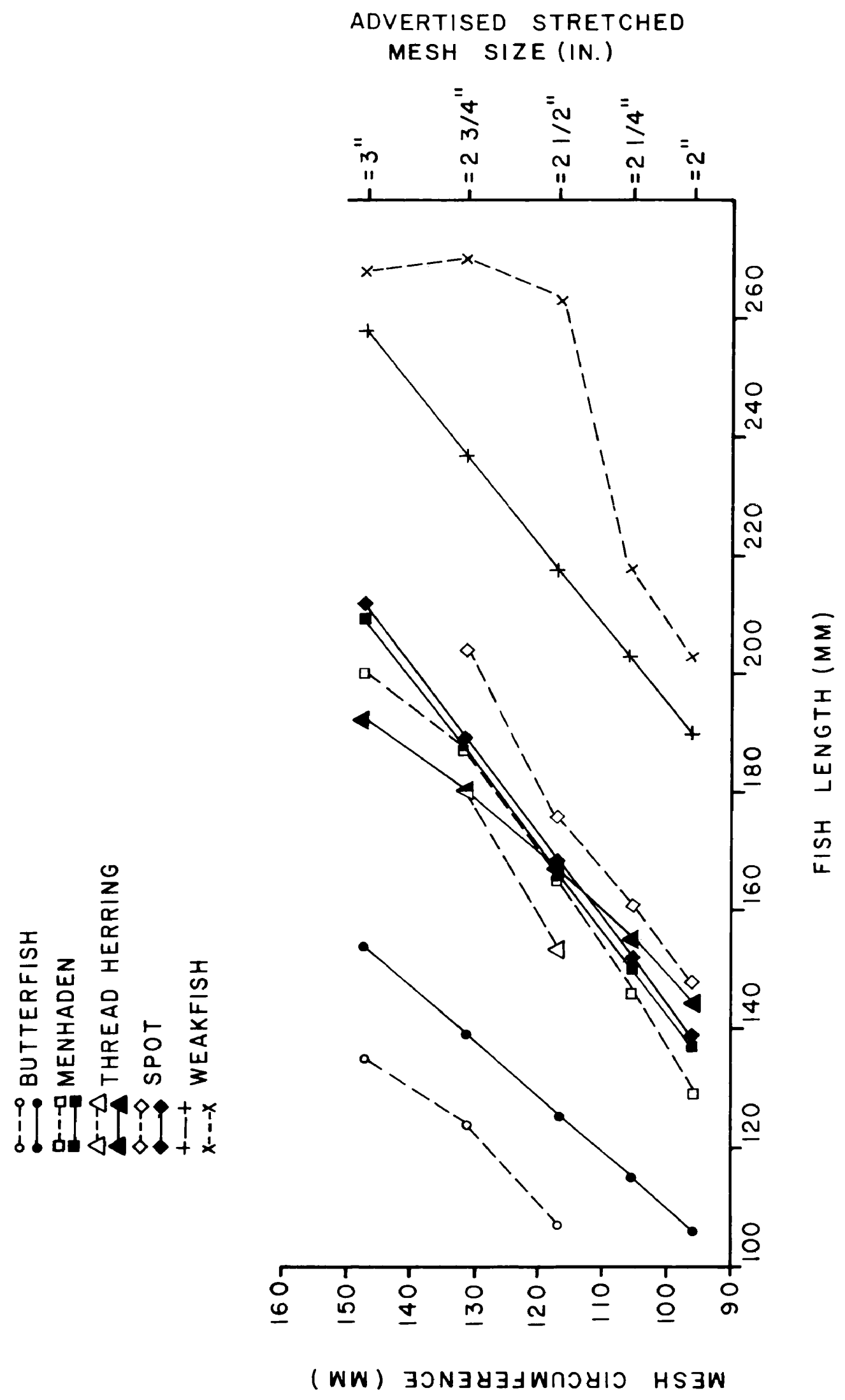




\section{DISCUSSION}

Stretched mesh size of conditioned, copper-treated, wet netting was consistently smaller than new, untreated, dry mesh size by about $5.6 \mathrm{~mm}$. Working mesh.size may be influenced by physical stress on the mesh, antifouling treatments, and immersion in salt water. The combined effect of stretch and shrinkage factors was a smaller mesh size in working nets than in new netting. Therefore, mesh size measurements should be made while the gear is fishing when determining selectivity characteristics for a particular pound net.

The relationship between maximum girth and length was linear for all species tested except thread herring for which my findings confinmed a disproportionate increase in body depth with length (Hildebrand, 1963). Mean fork length of thread herring increases slightly during the season while weight increases by approximately 20 per cent (McHugh, 1960), thus accounting for the relatively lower coefficient of determination. 'The low coefficient of determination obtained for weakfish was attributed to the distensible abdomen of this spocies. Variation in stonach fujuress manifested itseif as variable maximum girth for fish of approximately the same length. Naximum ginth was considered the most impontant facton determining fish escapement through a given mesh sire. Maxtmon girti values would approximate mean mesh circumerences it reshes confonm to the body of an escaping fish. 
It was reasoned that pound net heads, with their somewhat elastic meshes, allow this conformity. This reasoning proved only partially correct.

Theoretical 50\% retention lengths are of l-imited predictive value due to variability in body fomn, body firmness, and swimming ability of the fishes tested. Experimenta] 50\% retention lengths were shown to be the better descriptor of mesh selectivity although for menhaden, experimental and theoretical data did agree closely. True maximum girth of butterfish and thread herring at the experimental 50\% retention length was smaller than mean mesh circumference as both species are deep bodied, firm fleshed fishes. They probably don't succeed in conforming the mesh opening completely to their body at the point of maximuin girth when encountering a mesh. Thus theoretical retention values were overestimated for buttenfish and thread herring. Weakfish and spot are more circular in body cross-section than the other species, are strong swimmers, and have compressible abdomers. These attributes might allow them to squeeze through a mesh smaller than the maxinum girth. Unconstricted maximum girth at the experimental 50\% retention length was larger than mean mesh circumference thus causing underestimated theoretical retention values.

A seleation factor provides information regarding the harvest characteristics of a net for a given species of fish. It was assuned that a sinple lineax relationshjp existed betweon stretched mesh size and $50 \%$ rotontion longohs. Sooddy, the assumption was made that the so\% retontion longth could be 
calculated for any given mesh size, once a selection factor for a particular species in a fishing device of a given net material was known. Each selection relationship should be handled separately, however, when highly variable data are used such as that for weakfish.

The destruction of significant quantities of undersized and imnature weakish, spot, and butterfish by Virginia pound nets has been documented by McHugh (1960), joseph (.1962), and Massmann (1963). Between one-quarter and two-thirds of the total pound net catch of these species was treated as scrap. Menhaden and thread herring are non-food species taken in large quantities by pound nets. The majority of menhaden taken by this gear are in their first and second years of life (McHugh et al., 1959). Thread herring in the catch are generally mature fish (Joseph, 1962).

An increase in mesh size is warranted to allow escapement of undersized and imnature fishes, particularly the food and sport species. Return of escaped fishes to their native populations would increase availability of commercially jmportant sizes, assuming a uniform survival rate. Positive benefits of protective measures applied to a single area or type of gear could be negated, however, by increased exploitation by othex gears, or in nonregulated areas frequented by the same fish population.

A desirable maket size for the three food species considered herein was detemined by literature survey and intenview ${ }^{3}$ to be $305 \mathrm{~mm}$ (12 in) for weakfish, $165 \mathrm{~mm}$ ( $6.5 \mathrm{in}$ ) for butterfish, and $3.78 \mathrm{~mm}(7 \mathrm{in})$ for mot. 7 minimum manetable total length for weakfish of 305 mon wa provide an attractive protuct and assist 
in maintenance of a stable market since smaller fish could not flood markets and reduce prices. Escapement of fishes smaller than $305 \mathrm{~mm}$ would increase the size of the spawning population, since some females mature at about $190 \mathrm{~mm}$ and all are mature by approximately $270 \mathrm{~mm}$ (Higgins and Pearson, 1928). Butterfish $165 \mathrm{~mm}$ fork length and larger and spot $178 \mathrm{~mm}$ total length and larger have proven to be desirable marketable products.

Legislation to protect undersized fish has been proposed on several occasions. The Virginia Commission of Fisheries passed a "cull law" in 1914 (McHugh, 1960) which forbade retention of fish below certain minimum sizes. The difficulty of culling in * bad weather as well as time and effort expended offset benefits of future gains not immediately evident to the fishermen. Rough handling also jeopardized survival of undersized fish. The law failed to produce the results desired by its enactment.

Higgins and Pearson (1928) proposed a closed season for pound nets in Pamlico Sound, N.C. from the end of the shad season through August $I$ to prevent harvest of undersized weakfish and protect the spawning population. However, certain interest groups prevented adoption of the proposed closed season in its entirity. The closed season as adopted extended until June 1. This law proved of little consequence since pound nets were usually set in late May for the summer fishery. Despite failure to enact the original closed season, the landings in the weakfish fishery did not decrease (Roelofs, 1951). Roelofs (1951) further noted no increase in the weakfish population even though fewer pound nets have recently been fished in Pamlico 
Sound atter shad season. McHugh (1.960) considered closed seasons during midsunmer for the Virginia pound net fishery as an inadequate management policy.

Increased mesh size in pound net heads has been opposed on the grounds of increased gilling of fishes in larger meshes. Removal of gilled fish is time consuming and predators (sharks ard crats) damage the nets.

Mesh sizes larger than $50.8 \mathrm{~mm}$ ( 2 in) stretched were considered inpracticable for pound nets by Houston (1929) due to the quantities of fish gilled. McHugh (1960) however, concluded (p. 2): "In the absence of better documentary evidence, it can scarcely be maintained that the matter was settied adequately." Higgins and Pearson (1928) considered a small mesh size increase inadequate for escapement of significant quantities of undersized fish, since 127.0 to $152.4 \mathrm{~mm}$ ( 5 - 6 in) weakfish could be passed through $57.2 \mathrm{~mm}$ ( 2 I/4 in) stretched mesh manually but were retained by a net of the same mesh in fishing operations. My field results did not bean this out although quantities of undersized fish capable of escaping would probably be retained in a commercial pound-head when there is a large catch of small fish. A large catch increases strain on meshes thereby decreasing mesh flexibility, and can literally block open meshes.

Estination of optimum mesh size in a pound-hedd in this study was based on experimental retention curvos, preferred market sizes, biology of the species, and length Erequency d:stributions of Fish captured by pound nets in lower chesapeake Bay Derertised stretched mesh sizes of $69.8 \mathrm{~mm}(23 / 4 \mathrm{in}$ ) and 
$76.2 \mathrm{~mm}$ ( $3 \mathrm{in}$ ) proved undesirable since they allow escapement of salable spot (over $178 \mathrm{~mm}$ ) and produce significant gilling in all five species tested.

An advertised stretched mesh size of $63.5 \mathrm{~mm}(21 / 2 \mathrm{in})$ is not optimal since large quantities of weakfish, spot, and thread herring caught by pound nets in lower Chesapeake Bay are in the size ranges most subject to gilling. This mesh size would permit retention of most weakfish over $293 \mathrm{~mm}$ total length and spot over 188 mon total length. This was considered the best compromise in marketable lengths for these species. However, gilling was significant for three of the five species tested in this mesh size.

Large quantities of spot, menhaden, and thread herring in the size ranges most subject to gilling in an advertised stretched mesh size of $57.2 \mathrm{~mm}$ ( 2 1/4 in) are caught by lower Chesapeake Bay pound nets. Gilling was again significant for three of the five species tested. The entire size range of thread herring taken would probably become gilled in quantities exceeding the permissible level.

No mesh size tested allowed escapement of butterfish larger than the minimum proposed marketable length of $165 \mathrm{~mm}$ (6.5 in). This species was therefore excluded from the above evaluations. Protection of undersized fishes should be effective without being disruptive to operations of the fishery. Frotective measures must be based upon thorough study of their effect upon the future supply of fishes. As an interim policy, protective measures which partially fulfill the above limitations should 
be instituted where biological and economic benefits are expected to accrue. An increase in mesh size has been suggested by many individuals for this reason.

Selectivity of pound nets is related to 1) variability in fish girth and mesh size; 2) stretching or relaxing of meshes due to random or systematic stresses on the webbing; 3) blockage of meshes by seaweed, gilled fish, or a large catch; 4) physical and behavioral differences among various sizes and species of fishes affecting their ability to escape; and 5) tears in the net.

I consider the $50.8 \mathrm{~mm}$ ( 2 in) stretched mesh netting widely used in the pound net fishery of the lower Chesapeake Bay at present to be a necessary though wasteful compromise. Data indicated escapement of smaller fishes for all test species when a larger mesh size was used. However, increased frequency of gilling with increased mesh size offsets these benefits considerably.

Behavioral differences between sciaenids and clupeids in pound net heads could allow use of a panel of larger mesh size to effect escapement of undersized food fishes. Weakfish and spot congregate near the bottom in a pound-head while menhaden and thread herring remain near the surface. A panel of 57.2 $\mathrm{mm}$ (2 I/4 in) mesh size or larger in the floor of a pound-head could effect release of undamaged small sciaenids. Clupeids wouid remain relatively unaffected since the smaller mesh size in the side of the pound-head forms the final pocket in which the catch is concentrated. Stresses on meshes involved in actual pound-heads relative to experimental heads used in this 
study could assist in preventing gilling. Thus harvest of clupeids, necessary bait for the blue crab fishery, and a savings of undersized sciaenids could result.

The fishing industry would benefit from a fishing procedure or device which allows escapenent of unmarketable, immature. fishes without gilling. Benefits would include an increase in the number of spawning and marketable fishes in lower chesapeake Bay, a savings in culling time, better quality of the marketable catch, and possible market stability. Sport fishermen would benefit through a general increase in abundance of sport species

In summary, my recommerdations jnclude 1) use of in situ mesh size measurements when determining pound-head selectivity characteristics; 2) use of empirical data in computing $50 \%$ retention lengths; 3) establishment of minimum market size for weakfish (305 mm TL), butterfish (165 mm FL), and spot (178 mm TL); 4) a study of the projected effents of protective measures upon the resource; 5) continued research to fulfill the requirement imposed in 1952 by the State of Virginia; 6) a study to determine feasibility of the proposed escape panel under actual fishing conditions; and 7) establishment of interim protective measures where possible. 


\section{APPENDIX A}

Morphometric data obtained from spot, menhaden, butterfish, weakfish, and thread herring

(TL=total length, FL=fork length, OG=opercular

girth, MG=maximum body girth, MD=maximum body

depth, and MWmaximum body width)

\section{Variables \\ $x y$}

Spot

TI OG

TL $\quad$ MG

Equation

Equation

TL MD

TL NW

$Y=0.946+0.621 X$

210

0.96

.210

0.93

210

0.93

210

$Y=-0.101+0.1 .14 X$

Menhaden

FL OG

$$
Y=10.350+0.633 x
$$

209

$Y=10.023+0.657 X$

209

$Y=10.166+0.266 X \quad 209$

$Y=-3.866+0.146 \mathrm{X} \quad 209$

210

0.86

$75-155$

EL $\quad O G$

$$
Y=5.494+0.769 x
$$

210

0.89

$75-155$

FL $\quad M G$

$$
Y=-2.433+0.349 x
$$

210

0.89

$75-155$

FI

$$
M D
$$

$Y=-5.073+0.487 x$

27.0
Length range (mm)

$106-210$

$106-210$

$106-210$

$106-210$
EL

$M$

$Y=-2.124+0.135 x$

0.84

$75-155$ 


\section{APPENDIX A (cont.)}

\begin{tabular}{|c|c|c|c|c|c|c|}
\hline \multirow{2}{*}{\multicolumn{2}{|c|}{ Variables }} & \multirow[b]{2}{*}{ Equation } & \multirow[b]{2}{*}{$\mathrm{n}$} & \multirow{2}{*}{$r^{2}$} & \multicolumn{2}{|c|}{ Length } \\
\hline$x$ & & & & & rang & $e(\mathrm{~mm})$ \\
\hline \multicolumn{7}{|c|}{ Weakfish } \\
\hline TL & OG & $Y=8.865+0.428 X$ & 210 & 0.69 & 154 & -258 \\
\hline TL & MG & $Y=16.957+0.442 X$ & 210 & 0.58 & 154 & -258 \\
\hline TL & $M D$ & $Y=9.479+0.165 X$ & 210 & 0.44 & 154 & -258 \\
\hline TL & $M W$ & $Y=-0.615+0.105 X$ & 210 & 0.59 & 154 & -258 \\
\hline \multicolumn{7}{|c|}{ Thread Herring } \\
\hline FL & OG & Logy $=1.514+0.0029 x$ & 210 & 0.79 & 114 & $-192 \because$ \\
\hline FL & MG & Logy $=1.573+0.0029 x$ & 210 & 0.76 & 114 & -192 \\
\hline FL & MD & $Y=-1.860+0.333 x$ & 210 & 0.74 & 114 & -192 \\
\hline FL & MW & $Y=-4.380+0.140 X$ & 210 & 0.76 & 114 & -192 \\
\hline
\end{tabular}




\section{NOTES}

1 W. I. Wilson and J. W. Davis, The active pound net fishery in Virginia 1959-1972, manuscript report, Va. Inst. Mar. Sci., Department of Ichthyology.

2 One-third basis may be defined as the method whereby net mesh material is hung-in on a supporting line by $331 / 3 \%$ of its stretched length, i.e. $3 \mathrm{~m}$ of stretched mesh is attached to $2 \mathrm{~m}$ of supporting line.

3 H. N. Sadler, Fisheries Inspection Supervisor, Virginia Marine Resources Commission, Newport News, Virginia. 


\section{IITERATURE CITED}

Higgins, E., and J. C. Pearson. 1928. Examination of the summer fisheries of Pamlico and Core Sounds, N.C., with special reference to the destruction of undersized fish and the protection of the gray trout, Cynoscion regalis (BIoch and Schneider). Rept. U.S. Comm. Fish. for 1927; 29-65.

Hildebrand, S. F. 1963. Family Clupeidae, p. 257-454. In H. B. Bigelow (ed.), Fishes of the western North Atlantic. Mem. No. 1, Pt. 3, Sears Found: Mar. Res. 630 p.

Houston, H. R. 1929. Biennial report of the Commission of Fisheries of Virginia for the 30 th and 31 st years, July I, 1927, to June 30, 1929. Division of Purchase and Printing," Richmond. 23 p.

Joseph, E. B. 1962. Industrial or scrap-fish catch from pound nets in lower Chesapeake Bay - 1960. Va. Inst. Mar. Sci., Spec. Sci. Rep. No. 35. 47 p.

Massmann, W. H. 1963. Age and size composition of weakfish, Cynoscion regalis, from pound nets in Chesapeake Bay, Virginia 1954-1958. Chesapeake Sci. 4 (I): 43-5I.

Matugh, J. L., R. T. Oglesby, and A. L. Pacheco. 1959. Length,. weight, and age composition of the menhaden catch in Virginia waters. Limnol. Oceanogr. 4 (2): 145-162.

McHugh, J. L. 1960. The pound-net fishery in Virginia. Part 2Species composition of landings reported as menhaden. Comm. Fish. Rev. 22 (2): 1-16.

Reid, G. K., Jr. 1955. The pound-net fishery in Virginia. Part 1 - History, gear description, and catch. Comm. Fish. Rev. 17 (5): $1-15$.

Roelofs, E. W. 1951. The edible finfishes of North Carolina, p. 109-139. In H.w. Taylor et al., Survey of marine fisheries of North Carolina. Univ. N.C. Press, Chapel Hill. $555 \mathrm{p}$.

True, F. W. 1887. The pound-net fisheries of the Atlantic States, p. 595-610. In The fisheries and fishery industries of the United States. U.S. Comm. Fish and Fish., Sect. V, Vol. I, Pt. XI. 
Wyoski, R. S., and D. R. Wolfert. 1968. Th improved gintromites for studies of gill net seloctivity. Hog. Fishocult. 30 (1): $62-64$. 
VITA

\section{Henry Louis Meyer}

Born in Champaign, Illinois, April 27, 1946. Graduated from Arlington Heights Hjgh School in Eort worth, Texas, May 1964. B.S. in biology, Towson State College, Baltimore, Maryland, 1969. Laboratory technician, Department of Microbiology-Fathology, Virginia Institute of Maxine Science, 1971. M.A. candidate, School of Marire Science, College of William and Mary, entered as a graduate assistant in the Department of Ichthyology, 1971. 